McNeill, L.C., Dugan, B., Petronotis, K.E., and the Expedition 362 Scientists Proceedings of the International Ocean Discovery Program Volume 362

publications.iodp.org

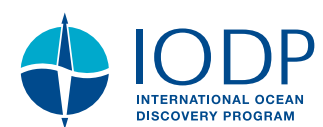

Check for updates

Contents

https://doi.org/10.14379/iodp.proc.362.202.2019

1 Abstract

\section{Data report: revised age models for IODP Sites U1480 and U1481, Expedition $362^{1}$}

Jan Backman, ${ }^{2}$ Wenhuang Chen, ${ }^{2}$ Sarah Kachovich, ${ }^{2}$ Freya Mitchison, ${ }^{2}$ Katerina Petronotis, ${ }^{2}$ Tao Yang, ${ }^{2}$ and Xixi Zhao ${ }^{2}$

Introduction

1 Methods

2 Results and discussion

6 Acknowledgments

6 References

Keywords: International Ocean Discovery Program, IODP, JOIDES Resolution, Expedition 362,

Site U1480, Site U1481, Sumatra Seismogenic Zone, age model

\begin{abstract}
A revised age model for Site U1480 was generated for the 0-67 Ma time interval using biomagnetostratigraphic data from which age-depth tie points have been selected to determine sediment accumulation rates and durations of identified hiatuses. This revised age model relies on biostratigraphic data between $\sim 2$ and $67 \mathrm{Ma}$ and biomagnetostratigraphic data between 0 and $1.8 \mathrm{Ma}$ and differs from the shipboard age model in terms of (1) the timing and duration of the major Cenozoic hiatus, (2) the late Miocene-early Pliocene transition, (3) the 0-1.8 Ma interval, and (4) the age of the sediment/volcanic interface at 1415 meters below seafloor (mbsf), here determined to be $\leq 67.4 \mathrm{Ma}$. Two intervals of igneous strata totaling $60 \mathrm{~m}$ occur in the Paleocene sedimentary rock sequence, giving a thickness of $1355 \mathrm{~m}$ for sediments and sedimentary rocks. In Hole U1481A, sedimentary rocks were recovered between 1150 and 1499 mbsf. The revised age model differs from the shipboard version mainly in more clearly acknowledging the lack of biostratigraphic data between 1411 and 1495 mbsf.
\end{abstract}

\section{Introduction}

Eight holes were drilled at Site U1480, recovering sediments and sedimentary rocks from the mudline to 1415 meters below seafloor (mbsf), whereas the single hole at Site U1481, located $35.7 \mathrm{~km}$ $(19.3 \mathrm{nmi})$ southeast of Site U1480, recovered sedimentary rocks between 1150 and 1499 mbsf. Both sites are presently located at >4 $\mathrm{km}$ water depth and are dominated by siliciclastic muds, muddy sands, and siliciclastic mudstone through $90 \%$ of the sedimentary sequence (see the Expedition 362 summary chapter [McNeill et al., 2017b]). The presence and abundance of the four microfossil groups investigated (calcareous nannofossils, diatoms, planktonic foraminifers, and radiolarians) are strongly variable with numerous barren samples. Preservation states vary for all four groups, when present, between poor and moderate.
The two sites moved from southern subtropical latitudes in the Paleocene to their present locations $2^{\circ}-3^{\circ}$ north of the Equator. We assume that age calibrations of individual marker species derived using magnetostratigraphy and/or cyclostratigraphy from subtropical to tropical latitudes are applicable to the corresponding marker species observed at Sites U1480 and U1481. Yet, the discontinuous and sporadic occurrences of age-calibrated marker species at these two sites prompted a different approach during the shipboard work, which is also adopted here. The presence of a species for which an age-calibrated extinction exists provides a youngest possible age for that sample depth, and the presence of a species for which an agecalibrated first evolutionary appearance exists provides an oldest possible age for that sample depth. Although this approach does not provide optimal age resolution for producing biostratigraphically based age models, it does provide reasonably well defined age constraints for many layers, permitting sediment accumulation rate (SAR) data to be established between selected age-depth tie points.

The biostratigraphic and SAR data, from older to younger, are presented in eight figures and six tables showing definitions of biostratigraphic tie points, depths, ages, and the resulting SARs connecting these tie points from the two sites.

\section{Methods}

The composite timescale adopted is identical to that used during Expedition 362 (see the Expedition 362 summary chapter [McNeill et al., 2017b]):

- Hilgen et al. (2012; table 29.3) from Top C1n through Base C6Cn.2n (0-23.030 Ma),

- Pälike et al. (2006; web table S 1 auto) from Base C6Cn.2r through Base C19n (23.278-41.510 Ma),

- Vandenberghe et al. (2012; table 28.3) from Base C19r through Base C29n (42.30-65.69 Ma), and

- Husson et al. (2011; table T3, option 2) from Base C29r though Base C31r (66.30-71.40 Ma).

${ }^{1}$ Backman, J., Chen, W., Kachovich, S., Mitchison, F., Petronotis, K., Yang, T., and Zhao, X., 2019. Data report: revised age models for IODP Sites U1480 and U1481, Expedition 362. In McNeill, L.C., Dugan, B., Petronotis, K.E., and the Expedition 362 Scientists, Sumatra Subduction Zone. Proceedings of the International Ocean Discovery Program, 362: College Station, TX (International Ocean Discovery Program). https://doi.org/10.14379/iodp.proc.362.202.2019

2 Expedition 362 Scientists' addresses.

MS 362-202: Received 29 October 2018 . Accepted 21 May 2019 . Published 2 September 2019

This work is distributed under the Creative Commons Attribution 4.0 International (CC BY 4.0) license. (c) BY 
Age estimates of individual biohorizons for calcareous nannofossils, diatoms, planktonic foraminifers, and radiolarians (see the Expedition 362 summary chapter [McNeill et al., 2017b]) and geomagnetic reversal boundaries in the $0-1.8 \mathrm{Ma}$ interval refer to this composite timescale.

Shipboard biostratigraphic data and methods of data acquisition (see the Expedition 362 summary chapter [McNeill et al., 2017b]) were combined with data acquired postexpedition. Tie points used for the determination of SARs are labeled using Cenozoic epochs $(\mathrm{Ple}=$ Pleistocene, $\mathrm{Pli}=$ Pliocene, $\mathrm{Mi}=$ Miocene, and $\mathrm{Pa}=$ Paleocene) plus numbers. For example, Ple1 through Ple8 range from younger to older tie points in the Pleistocene. Sediments deposited during the Late Cretaceous epoch were recovered from Hole U1480G and determined to be of (late) Maastrichtian age. Considering the long duration of the Late Cretaceous (43.5 My), the two Maastrichtian tie points employed are labeled Ma1 and Ma2 $(\mathrm{Ma}=$ Maastrichtian). Cenozoic tie points are thus labeled using the rank of epoch/series and the Mesozoic tie points using the rank of age/stage. Midpoint depths and/or ages are used for all tie points. Results are presented in stratigraphic order from older to younger.

\section{Results and discussion}

\section{Paleocene through late Maastrichtian}

The biostratigraphy of the Paleocene and upper Maastrichtian sediments in Hole U1480G is complicated not only by deep burial $(>1.3 \mathrm{~km})$, poor preservation, and reworking of Cretaceous taxa into Paleocene sediments but also by the presence of two discrete intervals of igneous strata, 22.40 and $37.45 \mathrm{~m}$ thick (Figure F1), within the Paleocene sediments. Each of these two igneous bodies may have formed instantaneously, and their total thickness of $59.85 \mathrm{~m}$ has distorted the biostratigraphic succession. When subtracting these strata bodies from the depth of the sedimentary section, the resulting (adjusted) depth scale provides a clearer view of the Paleocene accumulation pattern of sediments (Figure F2; see 362-202T01.xlsx in TABLES in Supplementary material).

Chalk in Sections 362-U1480G-61R-7 and 61R-CC (1326.82$1327.21 \mathrm{mbsf}$ ) is of late Paleocene age. Calcareous nannofossil assemblages show the presence of marker species Discoaster mohleri (base at $58.97 \mathrm{Ma}$ ) together with other late Paleocene taxa. These assemblages are quite diverse, so the absence of Discoaster multiradiatus (base at $57.22 \mathrm{Ma}$ ) indicates that this species had not yet evolved. The midpoint age between the base of $D$. mohleri and the base of $D$. multiradiatus is $58.1 \mathrm{Ma}$ (Tie Point Pa1), adopted here for Sample 61R-7, 55-56 cm (1326.82 mbsf), the uppermost of four samples in Sections 61R-7 and 61R-CC in which D. mohleri is present and $D$. multiradiatus is absent. The deepest and oldest Paleocene calcareous nannofossil assemblage observed in Sample 69R-8, $54 \mathrm{~cm}$ (1401.20 mbsf), contained Coccolithus pelagicus and Cruciplacolithus intermedius, indicating an age of $\leq 65.65 \mathrm{Ma}$ (Agnini et al., 2014; recalibrated to the adopted timescale).

Tie Point Pa2 is derived from the presence of Heliolithus cantabriae and absence of $D$. mohleri, indicating that the latter had not yet evolved. Tie Point Pa3 is based on the presence of Globanomalina compressa and absence of Praemurica uncinata, indicating that the latter had not yet evolved. The absence of the latter is further supported by the absence of early morozovellids, which have their first evolutionary appearance $0.14 \mathrm{My}$ after P. uncinata. A $1.7 \mathrm{My}$ long (65.2-66.9 Ma; see 362-202-T01.xlsx in TABLES in Supplementary material) hiatus is suggested across the Cretaceous/Paleogene boundary, occurring between the deepest (oldest) Paleocene
Figure F1. Biostratigraphy from $1326 \mathrm{mbsf}$ to volcanic basement (1415 mbsf; comb-shaped line), Hole U1480G. Right-pointing triangle = sample depth and estimated extinction age of a biohorizon (youngest possible age for the sample), left-pointing triangle $=$ sample depth and estimated first evolutionary appearance age of a biohorizon (oldest possible age for the sample). Black = calcareous nannofossils, orange $=$ planktonic foraminifers .

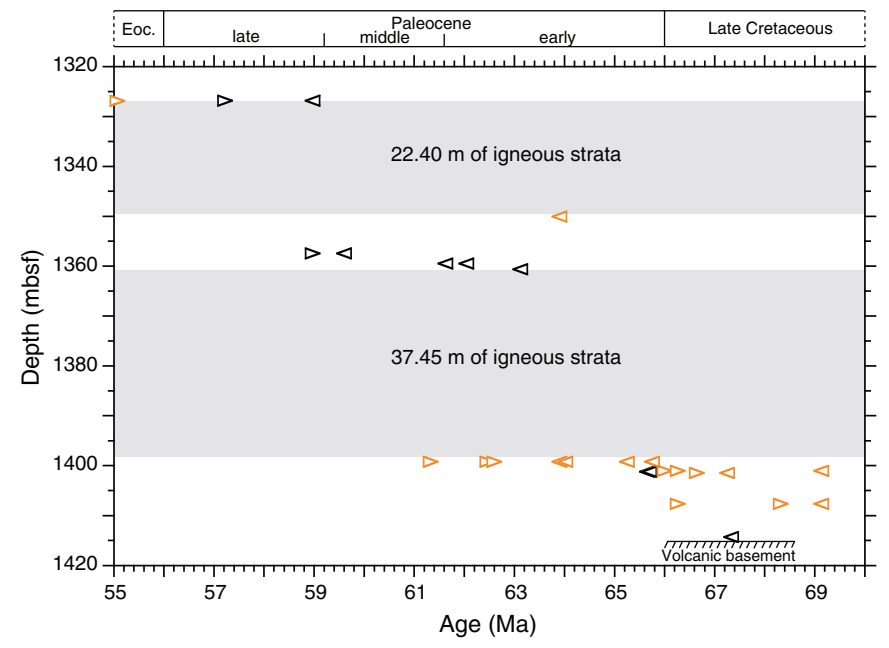

Figure F2. SARs from 1325 to 1355 mbsf, Hole U1480G. See Figure F1 for explanation of symbols. See 362-202-T01.xlsx in TABLES in Supplementary material for data. $\mathrm{Pa}=$ Paleocene, $\mathrm{Ma}=$ Maastrichtian. Gray solid circles $=$ tie points, dashed lines $=$ hiatuses. Black $=$ calcareous nannofossils, orange $=$ planktonic foraminifers.

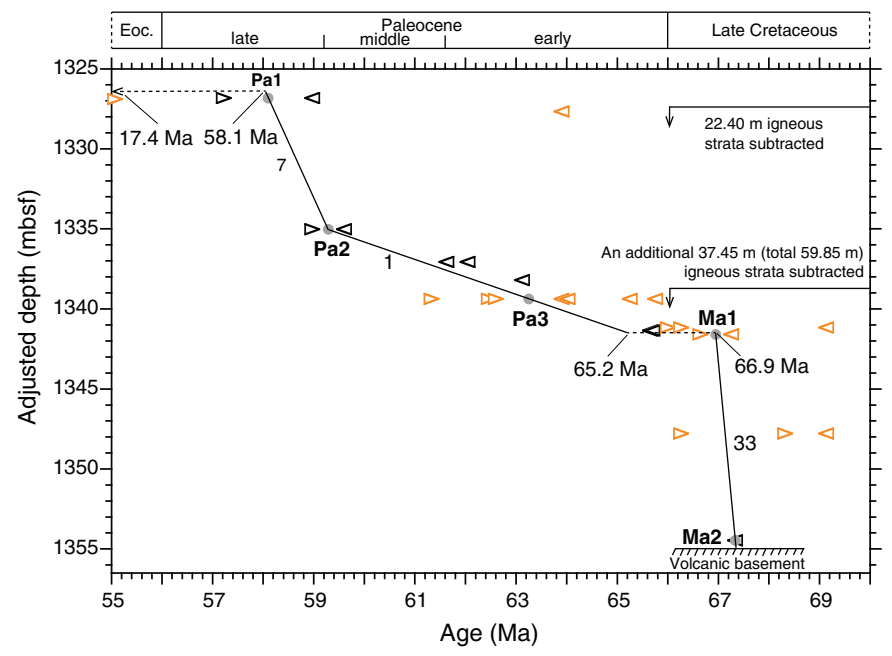

calcareous nannofossils in Sample 362-U1480G-69R-8, $54 \mathrm{~cm}$ (1401.20 mbsf), and the $0.25 \mathrm{~m}$ deeper, uppermost genuine late Maastrichtian assemblages of calcareous nannofossils and planktonic foraminifers in Sample 69R-CC (1401.45 mbsf). The hiatus is placed at the midpoint depth between these two samples; the latter represents Tie Point Ma1 (co-occurrence of Contusotruncana patelliformis and Pseudoguembelina hariaensis).

The position of two late Maastrichtian planktonic foraminiferal markers (top of Globotruncana spp. and top of Abathomphalus mayaroensis) in Sample 362-U1480G-69R-8, 34-36 cm (1401.01 mbsf), within the Paleocene with common Cretaceous calcareous nannofossil reworking is considered to reflect reworking and so is one marker (top of Globotruncana linneiana) in Sample 70R-CC (1407.64 mbsf). 
The oldest sediment investigated (Sample 362-U1480G-71R-2, $97 \mathrm{~cm} ; 1414.31 \mathrm{mbsf}$ ), located $1.04 \mathrm{~m}$ above the basaltic basement at 1415.35 mbsf, contains late Maastrichtian calcareous nannofossils including Micula murus (Tie Point Ma2). This species is known to be time transgressive, appearing later $(67.33 \mathrm{Ma})$ at intermediate latitudes in the North and South Atlantic, Indian Ocean, and northern Tethys (Thibault et al., 2010; 2012), and implies an oldest possible age extrapolated 1.04 $\mathrm{m}$ downhole from Tie Point Ma2 (base of M. murus) of 67.4 Ma for the sediment/basalt contact.

\section{A late Paleocene through early Miocene hiatus encompassing nearly $41 \mathrm{My}$}

Shipboard biostratigraphy indicated two condensed (2 and 4 $\mathrm{m} / \mathrm{My}$ ) intervals and two hiatuses between Sample 362-U1480G55R-CC (1269.16 mbsf) of early late Miocene age and Sample 61R7, $62 \mathrm{~cm}$ (1326.89 mbsf), of late Paleocene age. Subsequent postexpedition work revealed the presence of early Miocene radiolarians, calcareous nannofossils, and planktonic foraminifers in Sections 61R-5 and 61R-6.

The co-occurrence of two radiolarian species, Carpocanopsis favosa (top at $16.31 \mathrm{Ma}$ ) and Dorcadospyris dentata (base at 17.72 Ma), in Sample 362-U1480G-61R-5, 20 cm (1323.55 mbsf), provides a new early Miocene tie point (Mi5; midpoint age at $17.02 \mathrm{Ma}$ ) (Figure F3; see 362-202-T02.xlsx in TABLES in Supplementary material). The presence of the early Miocene calcareous nannofossil species Sphenolithus disbelemnos and the planktonic foraminiferal species Dentoglobigerina altispira in Sample 61R-6, 113-115 cm (1325.96 mbsf), suggests a hiatus between Sections 61R-7, $0 \mathrm{~cm}$ (1326.27 mbsf), and 61R-7, $56 \mathrm{~cm}$ (1326.83 mbsf). The midpoint depth (1326.55 mbsf) was used for the position of the hiatus. Extrapolating the SAR downhole from Tie Point Mi5 (1323.55 mbsf) to the hiatus depth at 1326.55 mbsf gives an age of 17.4 Ma for the end of the hiatus. Correspondingly, extrapolating the SAR uphole $0.27 \mathrm{~m}$ from Tie Point Pa1 (1326.82 mbsf) gives an age of 58.1 Ma for the onset of the hiatus, which therefore occupies $62 \%$ of the duration of the Cenozoic era. Four calcareous nannofossil and seven radiolarian markers from Sample 61R-5, 13-14 cm (1323.49 mbsf), to Sample 58R-1, 106-107 cm (1289.67 mbsf), observed 3-37 m above the hiatus do not fit the proposed age model. These are considered to represent reworking.

The underlying cause(s) of this $\sim 40.7$ My long hiatus remains unknown, although some combination of changing paleogeographic settings (including paleolatitudinal positions) and deep ocean circulation may have been at play.

\section{Late early through late Miocene in Hole U1480G}

The late early through late Miocene interval in Hole U1480G has a thickness of $566.95 \mathrm{~m}$ (1326.55-759.60 mbsf). According to the adopted age model of Hole U1480G (Figure F3), the late early Miocene (17.40-15.97 Ma) is $11.34 \mathrm{~m}$ thick (1326.55-1315.21 mbsf) and the middle Miocene (15.97-11.63 Ma) is $34.63 \mathrm{~m}$ thick (1315.21-1280.58 mbsf). It follows that the late Miocene is 520.98 $\mathrm{m}$ thick in Hole U1480G.

A modest SAR rate $(8 \mathrm{~m} / \mathrm{My})$ begins in the late early Miocene and lasts throughout the middle Miocene and into the early late Miocene. A near doubling of the rate to $15 \mathrm{~m} /$ My occurs at Tie Point Mi4 (1269.17 mbsf; $10.20 \mathrm{Ma}$ ), defined by the co-occurrence of Actinocyclus moronensis and Actinocyclus ellipticus f. lanceolata. A 15-fold increase in SAR occurs at Tie Point Mi3 (1255.17 mbsf; 9.26 Ma), defined by the presence of Didymocyrtis antepenultima, to 220 m/My and continues uphole to Tie Point Mi2 (795.63 mbsf; 7.17
Figure F3. SARs from 800 to 1400 mbsf, Hole U1480G. See Figure F1 for explanation of symbols. See 362-202-T02.xlsx in TABLES in Supplementary material for data. $\mathrm{Mi}=$ Miocene. Gray solid circles $=$ tie points, dashed line = hiatus. Black $=$ calcareous nannofossils, orange $=$ planktonic foraminifers, red $=$ diatoms, blue $=$ radiolarians .

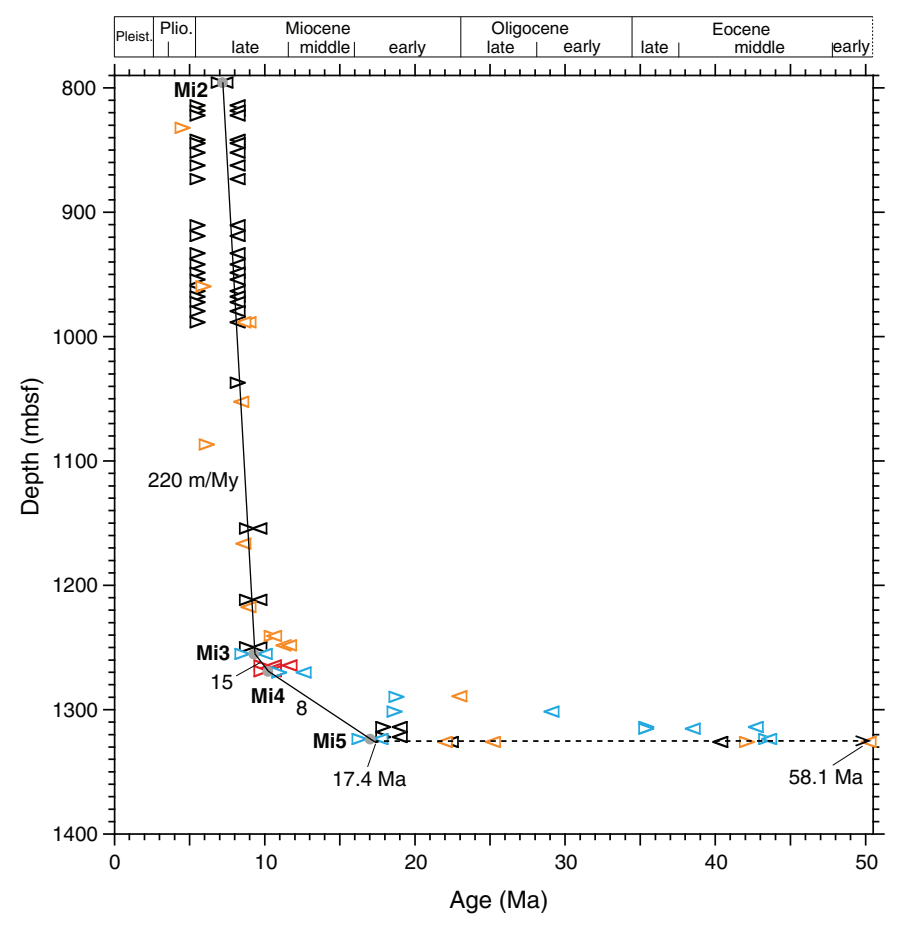

Ma; see 362-202-T02.xlsx in TABLES in Supplementary material), defined by the presence of Reticulofenestra rotaria, a species having a short range between 7.40 and 6.94 Ma (Raffi et al., 2003).

Available biostratigraphic data cannot resolve minor variations in SAR over the $459.54 \mathrm{~m}$ thick interval between Tie Points Mi3 and Mi2. These data however indicate that such variations must have been minor.

\section{Late Miocene through earliest Pleistocene in Holes $\mathrm{U} 1480 \mathrm{~F}$ and $\mathrm{U} 1480 \mathrm{H}$}

R. rotaria was also observed close to the bottom of Hole U1480F (Sample 362-U1480F-97X-CC, 4 cm; 795.91 mbsf), $0.28 \mathrm{~m}$ below its position in Hole U1480G, and is used here as an identical tie point (Mi2) and starting point in the age-depth history of Hole U1480F (Figure F4; see 362-202-T03.xlsx in TABLES in Supplementary material).

The $272.16 \mathrm{~m}$ thick interval from Sample 362-U1480F-97X-CC (795.91 mbsf) to 69X-1, 45-46 cm (523.76 mbsf), contains sporadic occurrences of Discoaster quinqueramus and Discoaster berggrenii, the latter present uphole to Sample 77X-CC (601.61 mbsf). D. quinqueramus disappears at $523.76 \mathrm{mbsf}$, and the following $48.6 \mathrm{~m}$ is barren of calcareous nannofossils from Samples 68X-CC (519.19 mbsf) to $64 X-C C$ (476.13 mbsf). The uppermost occurrence of $D$. quinqueramus at $523.76 \mathrm{mbsf}$ is therefore not considered to represent its well-dated extinction age at $5.53 \mathrm{Ma}$ but rather represents the effect of nonpreservation when moving uphole in Hole U1480F. Eleven samples were barren of calcareous nannofossils, Samples 68X-CC through 64X-CC.

Tie Points Pli2 and Pli1 rely on the presence of Ceratolithus acutus (5.36-5.04 Ma) and the top of Reticulofenestra pseudoumbilicus $(3.82 \mathrm{Ma})$, respectively, both well-dated calcareous 
Figure F4. SARs, Holes U1480H (0-80.57 mbsf) and U1480F (106.71$795.91 \mathrm{mbsf}$ ). See Figure F1 for explanation of symbols. See 362-202T03.xlsx in TABLES in Supplementary material for data. Ple = Pleistocene, $\mathrm{Pli}$ $=$ Pliocene. Gray solid circles $=$ tie points. Black $=$ calcareous nannofossils, orange $=$ planktonic foraminifers, red $=$ diatoms, blue $=$ radiolarians. Depth error bar for Tie Point Ple8 is shown.

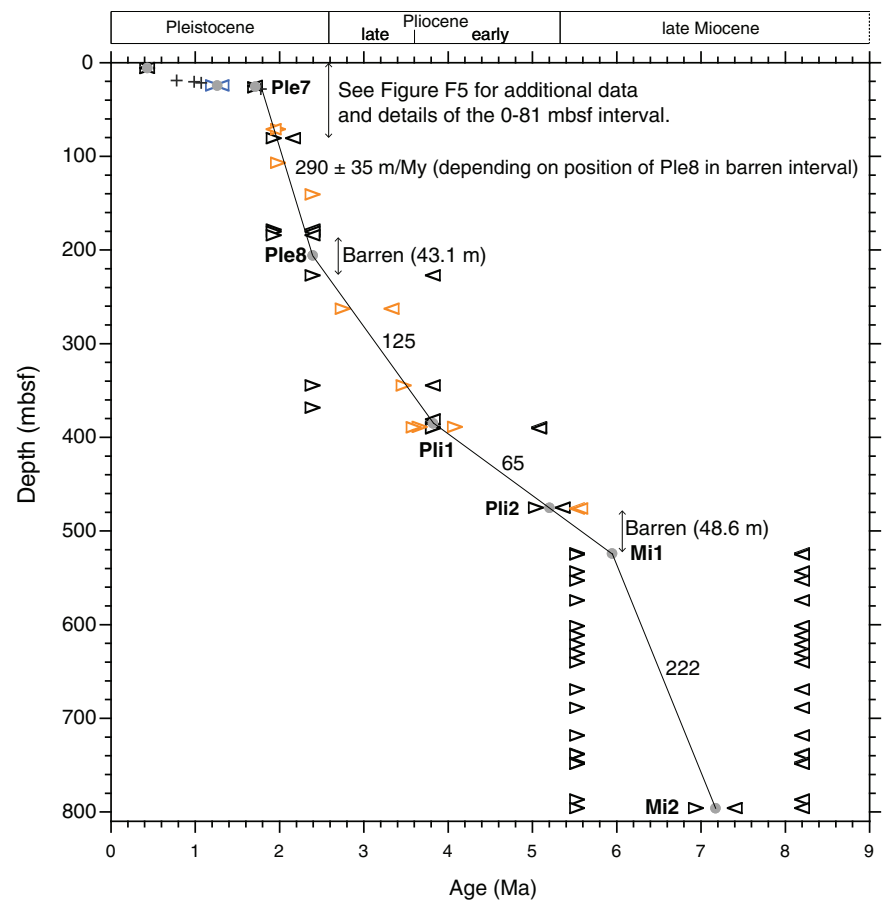

nannofossil markers. Using the midpoint age range of $C$. acutus $(5.20 \mathrm{Ma})$ and the top of $R$. pseudoumbilicus indicates a SAR of $65 \mathrm{~m} /$ My between these two tie points. This SAR was extrapolated downhole to the layer containing the uppermost occurrence of $D$. quinqueramus at $523.76 \mathrm{mbsf}$, generating an unconventional but reasonable tie point (Mi1) at 5.94 Ma (Figure F4; see 362-202T03.xlsx in TABLES in Supplementary material) given the lack of the genuine extinction level of $D$. quinqueramus in the $\sim 48.6 \mathrm{~m}$ thick carbonate-barren interval above. When connecting Tie Points Mi1 and Mi2 in Hole U1480F, the resulting SAR becomes 222 $\mathrm{m} / \mathrm{My}$, virtually identical to that calculated from the next two deeper tie points (Mi2 and Mi3) in Hole U1480G (220 m/My). Site U1480 therefore shows a SAR of $\sim 220 \mathrm{~m} /$ My from $1255.17 \mathrm{mbsf}$ $(9.26 \mathrm{Ma})$ to $523.76 \mathrm{mbsf}(5.94 \mathrm{Ma})$, where a 3.4-fold decrease in SAR occurs.

The Pliocene SAR nearly doubles to $125 \mathrm{~m} / \mathrm{My}$ between Tie Points Pli1 and Ple8, the latter representing the extinction of Discoaster pentaradiatus at 2.39 Ma (see 362-202-T03.xlsx in TABLES in Supplementary material). There is a depth uncertainty of 42.94 $\mathrm{m}$ between the uppermost sample that contains common $D$. pentaradiatus (362-U1480F-26F-1, $70 \mathrm{~cm} ; 227.10 \mathrm{mbsf})$ and the lowermost sample (17F-1, $3 \mathrm{~cm} ; 184.16 \mathrm{mbsf})$ that contains common Discoaster brouweri but lacks D. pentaradiatus. Six of the nine intervening samples are barren, and three show only rare calcareous nannofossils, two of which contain rare D. brouweri. These barren/rare occurrences explain the large depth uncertainty $( \pm 21.5 \mathrm{~m})$ given to Tie Point Ple8.
Figure F5. SARs from 0 to $80.57 \mathrm{mbsf}$, Hole U1480H. See Figure F1 for explanation of symbols. See 362-202-T04.xlsx in TABLES in Supplementary material for data. Gray solid circles = tie points. Black = calcareous nannofossils, orange $=$ planktonic foraminifers, red $=$ diatoms, blue $=$ radiolarians.$+=$ magnetostratigraphic reversal boundaries.

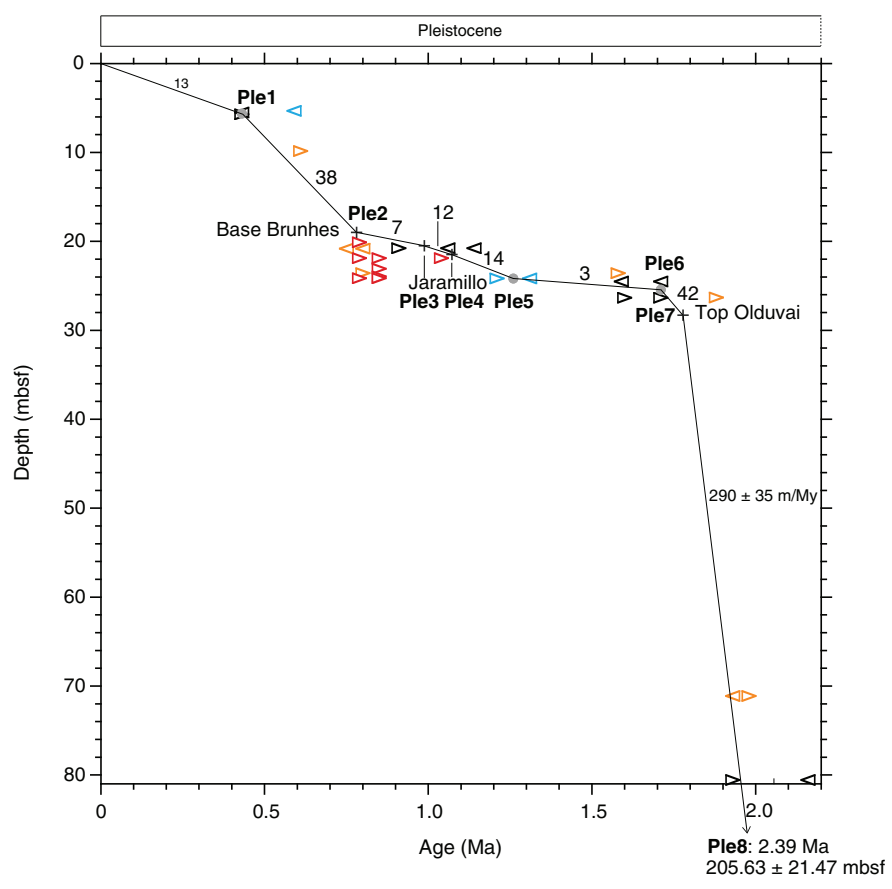

\section{Pleistocene in the uppermost $205 \mathrm{mbsf}$}

Discoaster triradiatus and D. brouweri co-occur in Sample 362$\mathrm{U} 1480 \mathrm{H}-10 \mathrm{H}-1,7 \mathrm{~cm}$ (80.57 mbsf). The former is rare through most of its range except during the most recent 0.23 My when its proportion increases to more than $10 \%$ relative to D. brouweri prior to their mutual extinction at $1.93 \mathrm{Ma}$ (Takayama, 1969; Backman and Pestiaux, 1987). These occurrences suggest that the SAR trend should pass between 2.16 and $1.93 \mathrm{Ma}$ at $80.57 \mathrm{mbsf}$.

Magnetostratigraphic data were reported from the uppermost $31 \mathrm{~m}$ in Hole U1480H (see the Expedition 362 summary chapter [McNeill et al., 2017b]). These data have undergone minor revision during postexpedition work. The base of the Brunhes Chron (base of C1n) occurs at $18.98 \pm 0.31$ mbsf (Figure F5; see 362-202T04.xlsx in TABLES in Supplementary material): the top of the Jaramillo Chron (top of C1r.1n) occurs at $20.49 \pm 0.17 \mathrm{mbsf}$, the base of the Jaramillo Chron occurs at $21.48 \pm 0.47 \mathrm{mbsf}$, and the top of the Olduvai Chron (C2n) occurs at $28.30 \pm 0.25$ mbsf.

When Tie Point Ple8 is connected to the top of the Olduvai Chron at 28.30 mbsf (Ple7), the SAR model passes through the $D$. brouweri-D. triradiatus time window at $80.57 \mathrm{mbsf}$, as predicted above. When taking into account possible depth extremes of Tie Point Ple8 (184.16-227.10 mbsf), the age at $80.57 \mathrm{mbsf}$ is between 1.94 and $1.98 \mathrm{Ma}$. The SAR between Tie Points Ple8 and Ple7 becomes $290 \pm 35 \mathrm{~m} / \mathrm{My}$. The uncertainty depends on the true position of Tie Point Ple8 in the $42.94 \mathrm{~m}$ carbonate-barren interval between 227.10 and 184.16 mbsf.

A 7-fold decrease in the SAR occurs at the top of the Olduvai Chron. SARs between 0 and 28.30 mbsf vary between 3 and 42 
Figure F6. Relative abundances of Pseudoemiliania lacunosa, counting $\geq 500$ specimens (notice scale difference of lower $x$-axes), and qualitative estimates of calcareous nannofossil abundance (abundant $=>50 \%$ [marker at $75 \%$ ], common $=10 \%-50 \%$ [marker at $30 \%$ ], few $=1 \%-10 \%$ [marker at $5 \%$ ], rare $=<1 \%$ [marker at $0.7 \%$, barren $=0 \%$ ), Hole U1480H.

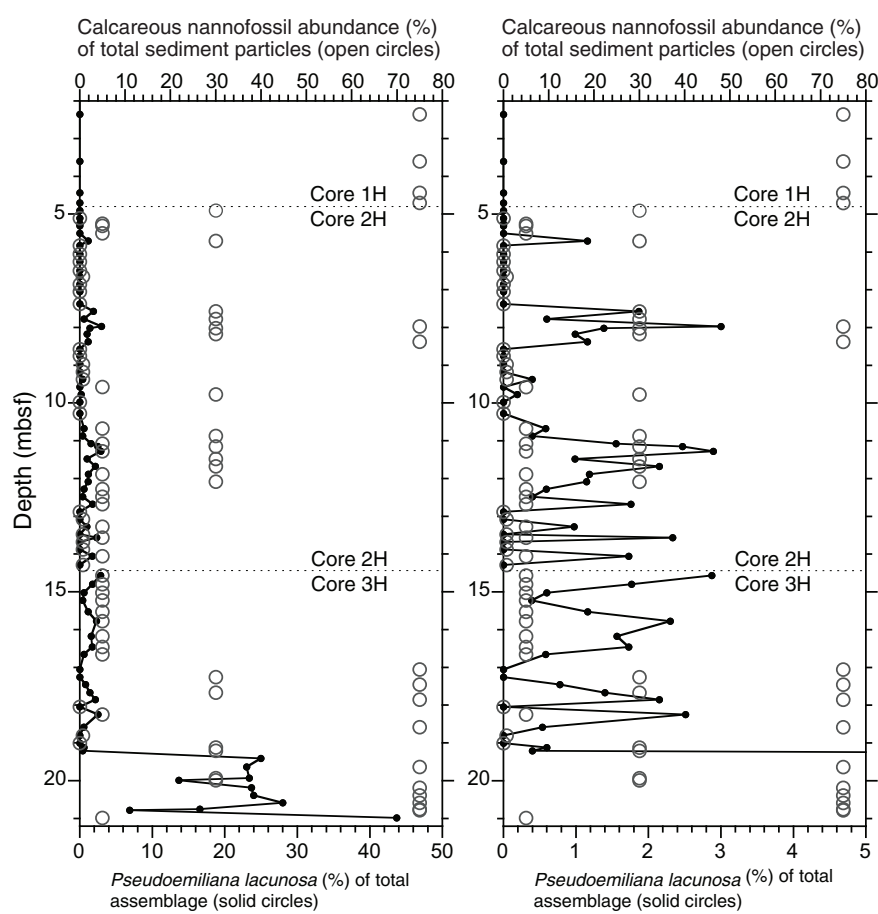

$\mathrm{m} / \mathrm{My}$, averaging $16 \mathrm{~m} / \mathrm{My}$. It remains unclear whether a hiatus is present between Tie Point Ple6 (base of Gephyrocapsa $\geq 4 \mu \mathrm{m}$ ) and Tie Point Ple5 (base of Lamrocyrtis nigriniae and top of Anthocyrtidium angulare) (Figure F5; see 362-202-T04.xlsx in TABLES in Supplementary material).

An alternative interpretation of the SAR between Tie Points Ple6 (25.43 mbsf; 1.71 Ma) and Ple5 (24.15 mbsf; $1.26 \mathrm{Ma})$ is found by extrapolating the SAR between Tie Points Ple8 and Ple7 up to $25.43 \mathrm{mbsf}$, resulting in an age of $1.77 \mathrm{Ma}$ at $25.43 \mathrm{mbsf}$. Correspondingly, extrapolating the SAR between Tie Points Ple5 (24.15 mbsf; 1.26 Ma) and Ple4 (21.48 mbsf; 1.072 Ma) downhole to $25.43 \mathrm{mbsf}$ results in an age of $1.35 \mathrm{Ma}$ for that depth. This alternative interpretation of the SAR history implies the presence of a hiatus at $25.43 \mathrm{mbsf}$ that begins at $1.77 \mathrm{Ma}$ and ends at $1.35 \mathrm{Ma}$ (not shown in Figure F5).

A single tie point is used above the base of the Brunhes Chron (Tie Point Ple2), namely the top of Pseudoemiliania lacunosa (Tie Point Ple1), for determination of SARs in the uppermost $19 \mathrm{~m}$ in Hole $\mathrm{U} 1480 \mathrm{H}$. The extinction of this species is a well-established marker, consistently occurring during Marine Isotope Stage (MIS) 12 over wide geographic distances (e.g., Gartner, 1972; Thierstein et al., 1977; Flores et al., 2003; Backman et al., 2012). A sharp drop in abundance of P. lacunosa that occurs between Samples 362-U1480H-3H$5,10 \mathrm{~cm}$ (19.93 mbsf), and 3H-4, 79-80 cm (19.13 mbsf), was previously interpreted to represent its extinction (see the Expedition 362 summary chapter [McNeill et al., 2017b]). Subsequent counts of relative abundances at $\sim 25 \mathrm{~cm}$ resolution demonstrate that this species occurs sporadically through Sample $2 \mathrm{H}-1,120-121 \mathrm{~cm}$ (5.71 mbsf) (Figure F6), here re-interpreted to represent its genuine extinction and defining the SARs ( 38 and $13 \mathrm{~m} / \mathrm{My}$ ) in the uppermost $19 \mathrm{~m}$ above the base of the Brunhes Chron in Hole U1480H.
Figure F7. SARs, Site U1480. Gray solid circles = tie points. See 362-202T05.xlsx in TABLES in Supplementary material for tie point data. Numbers close to lines represent SAR (m/My).

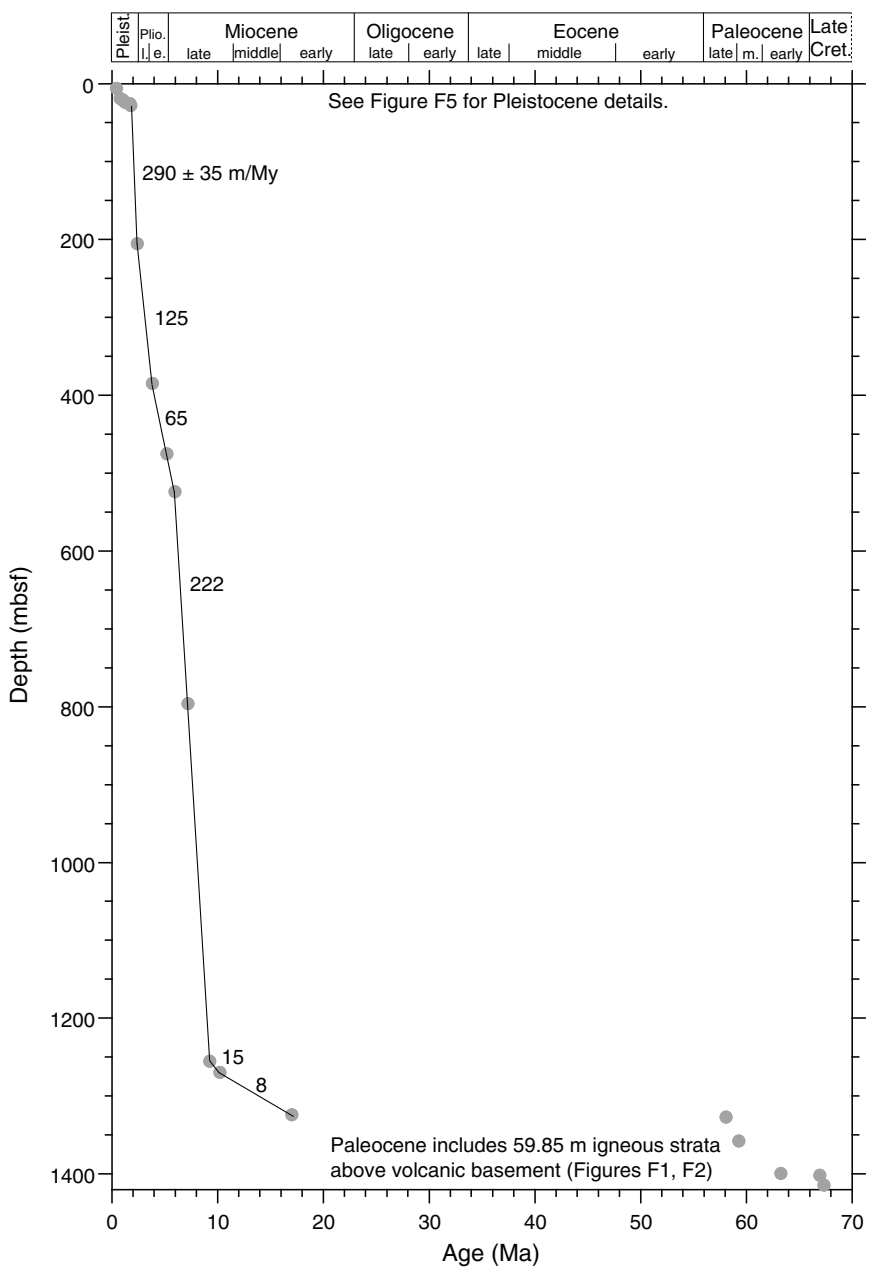

\section{Age model overview for Site U1480}

The SAR history at Site U1480 is summarized in Figure F7 and 362-202-T05.xlsx in TABLES in Supplementary material. This history can be divided into five age/depth intervals:

1. 67.4-58.1 Ma; $1415.35-1326.55 \mathrm{mbsf}(88.80 \mathrm{~m})$ : sedimentary rocks resting on the volcanic basement are of latest Maastrichtian age ( $\leq 67.4 \mathrm{Ma})$. The Cretaceous/Paleogene boundary is not recovered because of a hiatus. Two units of igneous strata interfingered into the Paleocene sediment column blur the accumulation history of the sedimentary rocks. These igneous strata have a total thickness of $59.85 \mathrm{~m}$, leaving $28.95 \mathrm{~m}$ for the preserved Maastrichtian and Paleocene sedimentary rocks. When the thickness of these igneous strata are subtracted, SARs range from 1 to $33 \mathrm{~m} / \mathrm{My}$.

2. 58.1-17.4 Ma; $1326.55 \pm 0.28$ mbsf: a major hiatus in the Site U1480 sedimentary record encompasses $62 \%$ (40.7 My) of the Cenozoic, the cause(s) of which is unknown.

3. 17.4-9.26 Ma; $1326.55-1255.17$ mbsf (71.38 m): once sediment preservation resumed at 17.4 Ma following the major Cenozoic hiatus, SARs are modest $(8 \mathrm{~m} / \mathrm{My})$ during the latest early Miocene through middle Miocene, followed by a near 2-fold increase $(15 \mathrm{~m} / \mathrm{My})$ in the early late Miocene. In this interval, pyri- 
tized radiolarians and diatoms are preserved below 1255 and 1264 mbsf, respectively.

4. 9.26-1.778 Ma; 1255.17-28.30 mbsf (1226.87 m): an abrupt 15fold increase in SAR, from 15 to $220 \mathrm{~m} / \mathrm{My}$, occurs at $1255 \mathrm{mbsf}$ (9.26 Ma). Average SAR from 9.26 to $1.778 \mathrm{Ma}$ is $164 \mathrm{~m} / \mathrm{My}$ and ranges from 65 to $290 \mathrm{~m} / \mathrm{My}$. This huge increase in SAR in the early late Miocene is discussed by McNeill et al. (2017a) in terms of Himalayan erosion and Nicobar Fan development.

5. 1.778-0 Ma; 28.30-0 mbsf (28.3 m): SARS calculated from biomagnetostratigraphic data in the $0-28.30$ mbsf interval of Hole $\mathrm{U} 1480 \mathrm{H}$ are an average of $16 \mathrm{~m} / \mathrm{My}$. An unresolved hiatus may be present in the $1.28 \mathrm{~m}$ thick interval between Tie Points Ple5 and Ple6.

\section{Comparison between Site U1480 and Site U1481}

Hole U1481A was drilled without coring to 1149.7 mbsf, where continuous coring began. Shipboard biostratigraphic data are for the age model in Figure F8 (see the Expedition 362 summary chapter [McNeill et al., 2017b]). A distinct change in lithology at 1360.12 mbsf marks the boundary between Lithostratigraphic Units II and III and corresponds to the Subunit IIC/IIIA boundary at 1250.36 mbsf in Hole U1480G (McNeill et al., 2017b). This lithostratigraphic boundary is considered to be synchronous in the two holes and occurs $109.77 \mathrm{~m}$ deeper in Hole U1481A (Figure F8). In both holes, the radiolarian marker $D$. antepenultima was used as a biostratigraphic tie point shortly below the lithostratigraphic unit boundaries mentioned above, $114.88 \mathrm{~m}$ deeper in Hole U1481A (1370.05 mbsf) than its position in Hole U1480G (1255.17 mbsf).

Correlations between the two holes are based on biostratigraphic and lithologic core analysis and core-seismic integration. McNeill and others observed that "The appearance of sandstone at $\sim 19 \mathrm{Ma}$ at Site U1481 suggests an earlier period of relatively coarser grained siliciclastic input and fan accumulation that is absent at Site U1480, potentially due to topographic variations," providing a reasonable explanation of the difference in stratigraphic thickness between the two sites.

In Hole U1481A, the upper tie point is located in Core 2R-CC (1554.36 mbsf) and has an age range between $8.20 \mathrm{Ma}$ (below the base of D. berggrenii with the presence of Discoaster bellus) and 8.80 Ma (above the base of the absence of $R$. pseudoumbilicus). By connecting to the second tie point based on the presence of $D$. antepenultima (Sample 24R-5, 84-86 cm; 1370.05 mbsf; $9.26 \mathrm{Ma}$ ), the SAR becomes $284 \mathrm{~m} / \mathrm{My}$ (Figure F8; see 362-202-T06.xlsx in TABLES in Supplementary material). Deeper than $1370.05 \mathrm{mbsf}$, the SAR history becomes uncertain, partly because of a $\sim 77.5 \mathrm{~m}$ thick interval lacking microfossils. However, downhole extrapolation of the 284 m/My SAR from 1370.05 mbsf to Sample 28R-6, 6-8 cm (the presence of Diartus hughesi; 1398.92 mbsf; 8.39-9.73 Ma), fits all available biostratigraphic data. In Hole U1480G, the 15-fold SAR increase uphole from 15 to $220 \mathrm{~m} / \mathrm{My}$ is placed at $9.3 \mathrm{Ma}$ (Figure F8). At Site U1481, the onset of a potentially corresponding major SAR change is obscured by the lack of biostratigraphic data.

The very bottom of Hole U1481A contains early Miocene to earliest middle Miocene diatom and radiolarian markers that line up across a narrow depth interval $(1.73 \mathrm{~m})$ over a $6.9 \mathrm{My}$ long age span, a classic indication of a hiatus.
Figure F8. Comparison of SARs, Holes U1480G and U1481A. See Figure F1 for explanation of microfossil symbols. The two tie points for Hole U1481A are unlabeled. See 362-202-T06.xlsx in TABLES in Supplementary material for data. IIC/IIIA and II/III = co-eval lithostratigraphic unit boundaries $(109.77 \mathrm{~m}$ deeper in Hole U1481A) (see the Expedition 362 summary chapter [McNeill et al., 2017b]). Black = calcareous nannofossils, orange = planktonic foraminifers, red $=$ diatoms, blue $=$ radiolarians .

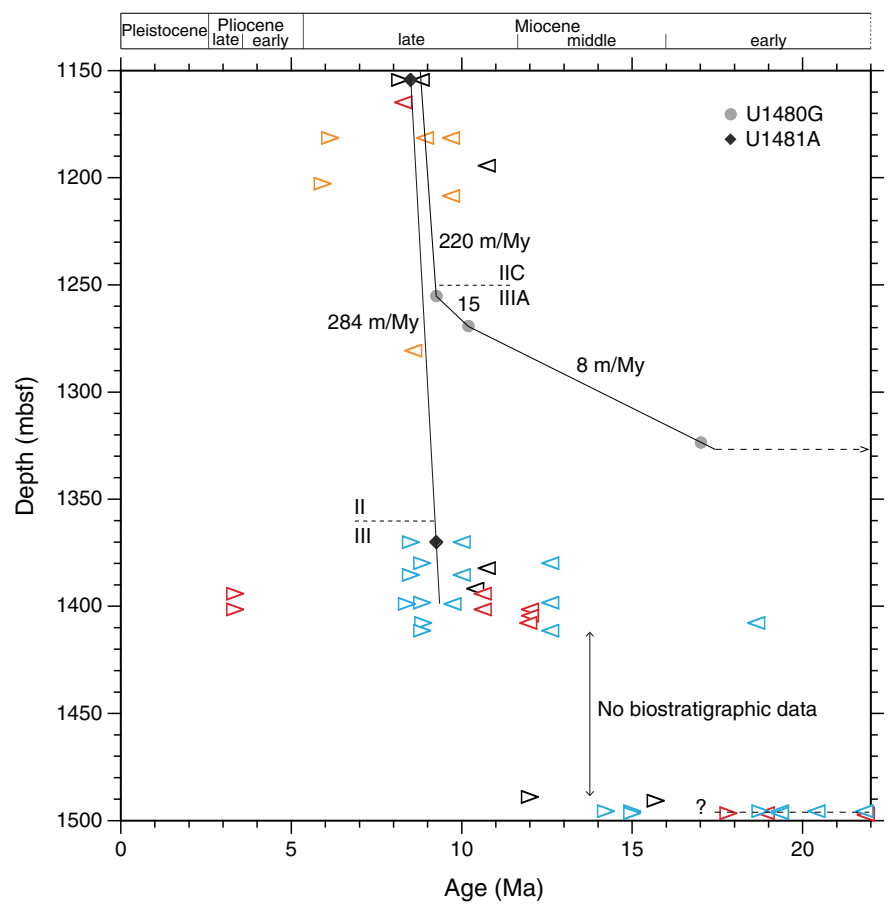

\section{Acknowledgments}

This research used data and samples provided by the International Ocean Discovery Program (IODP). We thank the IODP Expedition 362 crews and shipboard scientists, who all contributed greatly to make this endeavor a truly enjoyable experience. Comments by an anonymous reviewer improved the manuscript. J. Backman acknowledges financial support from the Swedish Research Council and the Bolin Centre for Climate Research (RA6).

\section{References}

Agnini, C., Fornaciari, E., Raffi, I., Catanzariti., R., Pälike, H., Backman, J., and Rio, D., 2014. Biozonation and biochronology of Paleogene calcareous nannofossils from low and middle latitudes. Newsletters on Stratigraphy, 47(2):131-181. https://doi.org/10.1127/0078-0421/2014/0042

Backman, J., Chen, W., Kachovich, S., Mitchison, F., Petronotis, K., Yang, T., and Zhao, X.X., 2019. Supplementary material,

https://doi.org/10.14379/iodp.proc.362.202supp.2019. Supplement to Backman, J., Chen, W., Kachovich, S., Mitchison, F., Petronotis, K., Yang, T., and Zhao, X.X., 2019. Data report: revised age models for IODP Sites U1480 and U1481, Expedition 362. In McNeill, L.C., Dugan, B., Petronotis, K.E., and the Expedition 362 Scientists, Sumatra Subduction Zone. Proceedings of the International Ocean Discovery Program, 362: College Station, TX (International Ocean Discovery Program). https://doi.org/10.14379/iodp.proc.362.202.2019 
Backman, J., and Pestiaux, P., 1987. Pliocene Discoaster abundance variations, Deep Sea Drilling Project Site 606: biochronology and paleoenvironmental implications. In Ruddiman, W.F., Kidd, R.B., Thomas, E., et al., Initial Reports of the Deep Sea Drilling Project, 94: Washington, DC (U.S. Govt. Printing Office), 903-910. https://doi.org/10.2973/dsdp.proc.94.126.1987

Backman, J., Raffi, I., Rio, D., Fornaciari, E., and Pälike, H., 2012. Biozonation and biochronology of Miocene through Pleistocene calcareous nannofossils from low and middle latitudes. Newsletters on Stratigraphy, 45(3):221-244. https://doi.org/10.1127/0078-0421/2012/0022

Flores, J.-A., Marino, M., Sierro, F.J., Hodell, D.A., and Charles, C.D., 2003. Calcareous plankton dissolution pattern and coccolithophore assemblages during the last $600 \mathrm{kyr}$ at ODP Site 1089 (Cape Basin, South Atlantic): paleoceanographic implications. Palaeogeography, Palaeoclimatology, Palaeoecology, 196(3-4):409-426. https://doi.org/10.1016/S0031-0182(03)00467-X

Gartner, S., 1972. Late Pleistocene calcareous nannofossils in the Caribbean and their interoceanic correlation. Palaeogeography, Palaeoclimatology, Palaeoecology, 12(3):169-191. https://doi.org/10.1016/0031-0182(72)90058-2

Hilgen, F.J., Lourens, L.J., and Van Dam, J.A., 2012. The Neogene period. With contributions by A.G. Beu, A.F. Boyes, R.A. Cooper, W. Krijgsman, J.G. Ogg, W.E. Piller, and D.S. Wilson. In Gradstein, F.M., Ogg, J.G., Schmitz, M.D., and Ogg, G.M. (Eds.), The Geologic Time Scale: Oxford, United Kingdom (Elsevier), 923-978. https://doi.org/10.1016/B978-0-444-59425-9.00029-9

Husson, D., Galbrun, B., Laskar, J., Hinnov, L.A., Thibault, N., Gardin, S., and Lockair, R.E., 2011. Astronomical calibration of the Maastrichtian (Late Cretaceous). Earth and Planetary Science Letters, 305(3-4):328-340. https://doi.org/10.1016/j.epsl.2011.03.008

McNeill, L.C., Dugan, B., Backman, J., Pickering, K.T., Pouderoux, H.F.A., Henstock, T.J., Petronotis, K.E., et al., 2017a. Understanding Himalayan erosion and the significance of the Nicobar Fan. Earth and Planetary Science Letters, 475:134-142. https://doi.org/10.1016/j.epsl.2017.07.019

McNeill, L.C., Dugan, B., Petronotis, K.E., Backman, J., Bourlange, S., Chemale, F., Chen, W., Colson, T.A., Frederik, M.C.G., Guèrin, G., Hamahashi, M., Henstock, T., House, B.M., Hüpers, A., Jeppson, T.N., Kachovich, S., Kenigsberg, A.R., Kuranaga, M., Kutterolf, S., Milliken,
K.L., Mitchison, F.L., Mukoyoshi, H., Nair, N., Owari, S., Pickering, K.T., Pouderoux, H.F.A., Yehua, S., Song, I., Torres, M.E., Vannucchi, P., Vrolijk, P.J., Yang, T., and Zhao, X., 2017b. Expedition 362 summary. In McNeill, L.C., Dugan, B., Petronotis, K.E., and the Expedition 362 Scientists, Sumatra Subduction Zone. Proceedings of the International Ocean Discovery Program, 362: College Station, TX (International Ocean Discovery Program). https://doi.org/10.14379/iodp.proc.362.101.2017

Pälike, H., Norris, R.D., Herrle, J.O., Wilson, P.A., Coxall, H.K., Lear, C.H., Shackleton, N.J., Tripati, A.K., and Wade, B.S., 2006. The heartbeat of the Oligocene climate system. Science, 314(5807):1894-1898. https://doi.org/10.1126/science.1133822

Raffi, I., Mozzato, C., Fornaciari, E., Hilgen, F.J., and Rio, D., 2003. Late Miocene calcareous nannofossil biostratigraphy and astrobiochronology for the Mediterranean region. Micropaleontology, 49(1):1-26. https://doi.org/10.2113/49.1.1

Takayama, T., 1969. Discoasters from the Lamont Core V21-98 (Preliminary Reports of the Philippine Sea cores, part 2). Bulletin of the National Science Museum (Tokyo), 12:431-450.

Thibault, N., Gardin, S., and Galbrun, B., 2010. Latitudinal migration of calcareous nannofossil Micula murus in the Maastrichtian: implications for global climate change. Geology, 38(3):203-206. https://doi.org/10.1130/G30326.1

Thibault, N., Husson, D., Harlou, R., Gardin, S., Galbrun, B., Huret, E., and Minoletti, F., 2012. Astronomical calibration of upper Campanian-Maastrichtian carbon isotope events and calcareous plankton biostratigraphy in the Indian Ocean (ODP Hole 762C): implication for the age of the Campanian-Maastrichtian boundary. Palaeogeography, Palaeoclimatology., Paleoecology, 337-338:52-71. https://doi.org/10.1016/j.palaeo.2012.03.027

Thierstein, H.R., Geitzenauer, K.R., Molfino, B., and Shackleton, N.J., 1977. Global synchroneity of late Quaternary coccolith datum levels validation by oxygen isotopes. Geology, 5(7):400-404. https://doi.org/10.1130/0091-7613(1977)5<400:GSOLQC >2.0.CO;2

Vandenberghe, N., Hilgen, F.J., and Speijer, R.P., 2012. The Paleogene period. With contributions by J.G. Ogg, F.M. Gradstein, O. Hammer, C.J. Hollis, and J.J. Hooker. In Gradstein, F.M., Ogg, J.G., Schmitz, M.D., and Ogg, G.M. (Eds.), The Geological Time Scale 2012: Amsterdam (Elsevier), 855-921. https://doi.org/10.1016/B978-0-444-59425-9.00028-7 